\title{
Collaboration the Role of Doctors and Pharmacers in Rational Preparation in Rantauprapat Hospital, Constraints and Its Efforts
}

\author{
Fifin Indira Lubis ${ }^{1}$, Zulfendri $^{2}$, Jumirah $^{3}$ \\ 1,2,3Faculty of Public Health, Universitas Sumatera Utara, Sumatera Utara, Indonesia \\ Email: pizqolubis@yahoo.co.id
}

\begin{abstract}
Rational prescribing is an important element in achieving the quality of health services which is one indicator in patient safety in hospital. The purpose of this study was to find out how the collaboration of the role of doctors and pharmacists in rational prescribing at Rantauprapat District Hospital. The research methodology uses a qualitative method with a phenomenological approach. Data was collected through in-depth interviews with doctors and pharmacists on duty at Rantauprapat District Hospital. The results showed that the form of collaboration between doctors and pharmacists in rational prescribing conducted at Rantauprapat District Hospital included: reviewing prescription contents, solving problems related to drug use and providing drug information. The results also showed that the obstacles in implementing collaborative roles of doctors and pharmacists included: the problem of the quantity of pharmacists that did not meet the standards and the limited pharmacist's knowledge of clinical pharmacy and the limited communication between doctors and pharmacists. Mitigation efforts include: recruiting pharmacists with clinical pharmacy qualifications, providing continuing education and training in clinical pharmacy to pharmacists, evaluating the implementation of pharmacy service policies in hospitals especially visits with doctors and pharmacists and building communication links between doctors and pharmacists through empowering the role of the pharmaceutical and therapeutic committee.
\end{abstract}

Keywords: rational prescribing; role of doctors; role of pharmacists

\section{Introduction}

Rational drug prescribing is an important element in achieving quality health care for patients and the community. This is one indicator in patient safety in hospitals established by the International Hospital Accreditation Organization (The Joint Commission on Accreditation of Healthcare Organizations / JCAHO). Irrational use of drugs is still commonly found in daily practice in the community. The irrational use of this drug can be in the form of drug use without any clear indication, determination of the dose, how to use the drug and the period of administration of the drug that is not right. The high price of drugs is also an example of the irrational prescription (Simatupang, 2014). In Indonesia the Patient Safety Incident Report found a case report of an Unwanted Event (KTD) of 14.41 percent and an Nearly Injury Incident (KNC) of 18.53 percent where a medication error occurred 9.26 percent (Patient Safety Committee at the Hospital, 2011). According to Habibah (2016), in his research at a hospital X found irrational prescriptions of $36.4 \%$, this form of irrational prescription includes overprescribing, under-prescribing, compound prescribing, wrong prescribing and luxury prescribing. Data from the systematic review conducted by Mao, et. al. (2014) that in China, half of antibiotic prescriptions do not comply with medical indications and in Vietnam this case occurs 35-60 percent. The results of the 2013 Australian National Antimicrobial Prescription Survey also showed that 151 hospitals in Australia found 22.9 percent of prescriptions for irrational antibiotics. This raises concerns about the relationship between irrational use of antibiotics and an increased risk of antimicrobial resistance (Broom, et. Al., 2015). Data from the systematic review conducted by Mao, et. al. (2014) that in China, half of antibiotic prescriptions do not 
comply with medical indications and in Vietnam this case occurs 35-60 percent. The results of the 2013 Australian National Antimicrobial Prescription Survey also showed that 151 hospitals in Australia found 22.9 percent of prescriptions for irrational antibiotics. This raises concerns about the relationship between irrational use of antibiotics and an increased risk of antimicrobial resistance (Broom, et. Al., 2015).

Incidence of patient safety incidents related to drug use, based on the 2006 IOM (Institute of Medicine) report on adverse drug events (ADE) experienced by patients, stated that incidents related to treatment ranked first. The $\mathrm{ADE}$ that occurred at the hospital added about 8,750 dollars to the hospital stay. Assuming 400,000 of these events each year (conservative estimates) the total annual cost would be 3.5 billion dollars in this one group. Another study found that ADE that could be prevented in the care of patients aged 65 years and over was 887 million dollars per year.

Based on the National Patient Safety Incident Report Report (Indonesian Hospital Unity Congress / PERSI September 2007), errors in drug administration in Indonesia rank first (24.8\%) of the top 10 reported incidents (Ministry of Health of the Republic of Indonesia, 2008). Furthermore, data from the Health Office of North Sumatra Province in 2018 shows that Labuhanbatu Regency is one of the regencies with rational drug prescription coverage of less than 60 percent.

Preliminary survey results at Rantauprapat Regional Hospital obtained data that in the period of January - September 2018 there were still 28.57 percent of prescription drugs that were not rational. The irrationality of prescription drugs consisted of compound prescriptions 38.7 percent, excess prescriptions 23.7 percent and prescriptions less 37.6 percent. In terms of prescribing antibiotics there are $16.6 \%$ of prescriptions that write a combination of two, three or even four types of antibiotics. This irrational prescription is most commonly found in the Functional Medical Unit (SMF) Obstetrics and Gynecology (Obstetrics and Gynecology), SMF Internal Medicine and SMF Children.

\subsection{Rational Prescribing}

The definition of prescription listed in the Regulation of the Minister of Health of the Republic of Indonesia number 72 of 2016 concerning Pharmaceutical Service Standards in Hospitals is writing which contains drug requests from doctors, dentists or veterinarians to pharmacists to prepare and provide medicines for patients in accordance with applicable regulations both in manual or digital form.

The ARS PRESCRIBENDI Book of Rational Prescriptions (Zaman and Joenoes, 1990) states that the complete contents of the recipe consist of: doctor's name, complete address, accompanied by a valid practice permit number and contact telephone number. Next in the upper right hand corner, write the name of the city and the date the recipe was written. At the beginning of the recipe is made an R / (which stands for recipe which means take it). which is called superscriptio. Name of medicine (inscriptio); can consist of: main drug (remedium cardinal), in addition may also be added drugs that support the work of the main drug (remedium adjuvans), as well as corringens which is a useful material to improve the taste, color or odor depending on the type of drug used, as well as constituents or vehicle; additives for medicinal concoctions and these additives must not be present. The name of the drug is also equipped with the amount of drug ingredients in units of weight (micrograms, milligrams, grams) and for solid preparations or unit contents (drops, milliliters, liters) for liquid 
preparations. Furthermore, also written the method of making or the desired dosage form, such as pulveres, ointments, tablets, capsules, injections and so on (subscriptio). Rules for the use of drugs written in Latin abbreviations (signatura), commonly abbreviated with "S", identification of patients consists of name, age, and address (pro) and ends with a doctor's signature or initial.

The Ministry of Health of the Republic of Indonesia in 2011 has published a Rational Treatment Module, the module mentions the criteria for rational drug use, including: the right diagnosis, the right drug selection, the right dose, the right way to use it, the right time interval, the right time of administration, the side effects alert, proper assessment of the patient's condition, right information, right dispensing, patient compliance.

To determine a prescription said to be irrational, the Ministry of Health of the Republic of Indonesia (2011) mentions that there are several criteria that can be used, among others: Overprescribing, that is, excessive prescription can be interpreted as the type and amount of drugs given that are not appropriate to the patient's disease and condition. Under prescribing. In contrast to over-prescribing, prescribing means that less than what is needed should be according to the diagnosis and condition of the patient, whether the dose is less than the effective dose of the drug, the quantity or quantity of drug is short or the length of time the treatment should be obtained (Multiple prescribing). Compound prescription that is giving more than five types of drugs in one prescription. Incorrect prescribing. Errors in prescribing include administration of drugs that are not in accordance with the indications that have been enforced, the presence of contraindications to the patient's condition, side effects have greater effect than the intended therapeutic effect, incorrect information about drug use, and so on.

\subsection{The Role of Doctors in Drug Prescribing}

Prescription writing is one of the competencies that must be possessed by a doctor in providing health services to patients as a whole through the application of science and pharmacology and therapeutic expertise safely, correctly and appropriately. Indonesian Doctors Competency Standards (SKDI) set by the Indonesian Medical Council (KKI) in 2012 that prescription writing is one of the competency components of a doctor.

In area seven in the management of health problems mentioned that a doctor must have skills in writing prescription drugs wisely. Prescription writing must be rational, which meets the criteria of the accuracy of the indication, the accuracy of the drug, the accuracy of the dose, the accuracy of the frequency and the accuracy of the means administration and compliance with the patient's condition. Recipe writing must also be clear, complete and readable. This is intended to avoid wrong interpretation (transcription) from the pharmacist caused by writing a doctor's prescription that is unclear or unreadable.

De Vries, et. al. (2014) in the Guidelines for Writing Good Prescriptions issued by WHO in the Action of the Essential Medicines Program in Geneva, Switzerland describes the steps in a rational treatment process, namely: Step 1: Define the patient's problem and establish a diagnosis. The general condition and the main complaint of the patient must be a priority in determining the choice of therapy or medication to be given. Step 2: Determine therapy and medication according to therapeutic goals to be achieved in treatment. Therapeutic goals to be achieved are also important to note because this will also affect the choice of drugs to be used. Sometimes there are cases of disease that cannot be treated suddenly or in a short time, where the effects received must be slowly so that the dosage or type of drug used is also different Step 3: Check the suitability of the therapy for the patient, both its effectiveness and safety. 
Appropriateness that is not less important is the cost, this may not be a problem for patients with insurance or with a good economic level, but for some people this can cause the therapy given to not produce the results as expected. Step 4: Start treatment. Starting treatment with the drug therapy of choice is given to patients either by the pharmacy directly or through the help of nursing staff in the treatment room. Step 5: Provide information, instructions and warnings. Patients must be given information about the effects of the drugs given. Possible side effects as well as symptoms of allergies or intolerance so that the patient understands what will be faced and no confusion occurs when receiving different effects. Information about how to use the drug, the duration of use and the expected effect must also be conveyed. It can also make it easier to find out the effect of an unwanted drug (Adverse Drug Reaction / ADR) early. Step 6: Monitor the patient's condition. Monitoring of therapy is done by monitoring the patient's condition. Monitoring is carried out by looking at the expected effects, the emergence of unexpected reactions (ADR). In this case it is necessary to evaluate the condition of the patient where collaboration between the doctor and the pharmacist is very important to be able to provide input to each other for the treatment of patients.

\subsection{The Role of Pharmacists in Drug Prescribing}

Indonesian Pharmacist Competency Standards in 2016 stated in the second Competency Standard, a two point one unit: a pharmacist must be able to carry out efforts in the rational use of drugs based on scientific evidence. These competencies include providing input on the selection / use and form of drug preparations, carrying out patient care processes by prescribing and dispensing drugs to patients, monitoring drug therapy by assessing the patient's condition, disease history and treatment history through measuring objective and subjective parameters and conducting analysis and resolving patient drug use issues with consideration of drug needs, therapeutic guidelines, cost considerations and applicable regulations.

\section{Research Method}

This type of research is a qualitative research with a phenomenological method approach. The study was conducted at Rantauprapat District Hospital, Labuhanbatu Regency, North Sumatra Province. The informants in this study were general practitioners and specialist doctors and pharmacists on duty at Rantauprapat District Hospital. The selection of informants uses a purposive sampling method, where researchers take doctor informants consisting of specialist doctors from several different SMFs and general practitioners and pharmacists consisting of the head of the pharmaceutical installation and the field implementing pharmacist. This study uses data collection techniques through in-depth interviews with research informants. Interviews are conducted in an open-ended and semi-structured manner, in which the researcher uses interview guides that are arranged in such a way as open-ended questions that enable the emergence of opinions and ideas from informants. Data analysis methods used in this study are the Miles and Huberman Models. There are three stages in data analysis in this model, namely data reduction, data display and conclusion drawing and verification.

\section{Research Results and Discussion}

From the results of interviews conducted with doctors and pharmacists, it can be seen the forms of collaborative roles between doctors and pharmacists carried out at Rantauprapat District Hospital, among others: 
Review the contents of the recipe. Prescriptions received by pharmacists must be reviewed in advance related to the problem of clarity of prescription writing, the complete contents of the prescription, the availability of drugs and the provisions of the use of drugs based on the national formulary and hospital formulary. For this reason, the pharmacist communicates with the doctor if problems are found. This can be seen in the following interview excerpts:

"If for example it is not clear what the doctor calls, like it doesn't read, like the dose isn't clear." (Pharmacist 1)

"For example, Lansoprazol, our stock is empty, companion pharmacy is also empty, we call the doctor, we are Lansoprazol, may we replace it with omeprazole. It's an alternative choice. "(Pharmacist 2)

"Whether included in the National Forum or not, can be claimed or not, that is the role of our pharmacists in hospitals to explain to doctors." (Pharmacist 3)

Resolution of problems related to drug use. Pharmacists also collaborate with doctors in solving problems related to drug use in patients. Forms of drug use problems in patients such as the use of two or more drugs with the same indication, contraindication problems,

"That sometimes there are drugs that have the same indication, written in double, that sometimes we often consult with the doctor in charge that there are two drugs that are the same indication, usually the average is antibiotics." (Pharmacist 3)

"Our case is with orthopedics, for example, then we forget or orthopedics forget to see our therapy, or there has already appeared an anti-pain doublel or antibiotic, well, here pharmacy sees irregularities, well they contact DPJP." (Doctors2)

"If there is a history of high blood pressure, if indeed the doctor made Sodium Diclofenac, we can consult a doctor, this doctor has a history of high blood pressure, should not potassium." (Doctor 4)

"Once, during accreditation (laughs), when we visited, we met interactions, we recommend that there be a drug that is stopped, so." (Pharmacist 4)

"For example, we deal with antibiotics, collaboration is called collaboration, what kind of collaboration, later side effects from the pharmacy, we know, not all doctors know sometimes the side effects, the dose is too excessive, the pharmacy can say that this dose must be adjusted Moreover, with the cooperation of other additional specialists, right? So, the other specialists will give this antibiotic. It is impossible for all antibiotics with the same class to be given sometimes, so from the pharmacy that will be known later. I see. "(Doctor 4)

Providing drug information. Drug Information Service Activity (PIO) is one of the duties and functions of pharmacists in providing and providing information about drugs to all health professionals who are on duty in hospitals and patients and other parties outside the hospital. The following phrase illustrates that doctors get drug information from pharmacists:

"I often ask the pharmacy, what are the side effects of this drug, if this drug and this drug can be combined or not? Sometimes we forget, new medicines. "(Doctor 1)

Abdul Kadir, et al (2017) write that to increase the effectiveness of teamwork collaboration between doctors and pharmacists requires the role of director. The developed three-party working group collaboration model (doctor-pharmacist-director) states that each of these parts has a role, namely: (1) The director has a role in the issuance of decisions on visite with doctors and pharmacists regarding rational care in hospitals, policies on the use of diagnostic guidelines, hospital formulas and therapies, and holding pharmacy and therapy committee meetings to report the results of care interventions conducted by pharmacists in terms of accountability for monthly reports for each treatment performed. (2) Doctors play a role in conducting joint visits, conducting discussions with pharmacists about care for patients and holding meetings in medical committees to report the results of care interventions carried out by pharmacists, (3) Pharmacists have a role in conducting joint visits, conducting independent visits and conducting discussions 
with doctors about care for patients.

Furthermore, the results of the study also showed obstacles in implementing collaborative roles of doctors and pharmacists. Based on the results of interviews conducted several problems were found in the implementation of the role of pharmacists in Rantauprapat District Hospital, including:

The problem of quantity and quality of human resources. One obstacle that was obtained based on the results of interviews conducted was the problem of the limited number of pharmacists on duty at Rantauprapat District Hospital and the ability of pharmacists in the field of clinical pharmacy. The quantity of pharmaceutical human resources at Rantauprapat District Hospital does not meet hospital class standards. This was revealed in the following interview excerpt:

"Yes to the limitations of HR" (Pharmacist 2)

"Yes, in terms of quality and quantity too" (Pharmacist 4)

"Actually, we have already been demanded by clinical pharmacy, clinical pharmacy should be collaboration with doctors, but it's only because of the limitations of buman resources that it's not working." (Pharmacist 3)

The standard for fulfilling the quantity of pharmacists in hospitals is based on the Regulation of the Minister of Health of the Republic of Indonesia number 56 of 2014 concerning Hospital Classification and Licensing which states that for non-educational class B hospitals the number of pharmacy consists of a minimum of 13 pharmacists and assisted by 20 text workers pharmacy. At Rantauprapat Regional Hospital, at the time of the study, the number of pharmacists was still seven people with 16 pharmacy technical personnel. This becomes an obstacle for pharmacists to be able to carry out pharmaceutical services, especially clinical pharmacy services.

Limited knowledge of clinical pharmacy. The quality of pharmaceutical human resources in Rantauprapat District Hospital has no clinical pharmacy education, so pharmacists have limitations in clinical pharmacy to be able to carry out services to patients or collaborate with doctors.

The problem of limited communication with doctors. Another problem found from the results of interviews conducted with pharmacists is the problem of communication between doctors and pharmacists. Some things related to communication between doctors and pharmacists include:

There are doctors who are difficult to communicate with. From the results of interviews conducted with pharmacists, barriers that are felt in communicating with doctors include doctors who are difficult to communicate with. Forms of communication difficulties that occur such as not receiving a call or not receiving input provided on the basis of personal consideration. This was obtained from the following interview excerpts:

"... if for example it is not clear what the doctor calls, often it is open, it doesn't look like it, it doesn't read, like the dose is not clear, the average is usually the doctor immediately picks up, but there are also those that are difficult right, right? if the doctor wants to take a nice phone when reviewing the prescription, we are afraid of the wrong prescription too, sometimes the doctor doesn't pick up ... "(Pharmacist 1)

"But there are some doctors we haven't asked yet, he already hung up right away." (Pharmacist 2)

"Sometimes there are some doctors who might have been using the same method of treatment, so we give 
input maybe he is lacking, it's just me who needs it, for example just different names be doesn't want, different names but the contents are the same, that's the case there that is, maybe considering patient comfort, or what, sometimes there are like that, usually senior doctors. "(Pharmacist 5)

Pharmacists do not have the confidence to communicate with doctors. Communication barriers also come from the pharmacists themselves who do not have confidence in communicating with doctors. This was acknowledged by one of the informants who was the head of the pharmaceutical installation as follows:

"Oh yeah ... these guys, I don't know if I'm afraid of something, I don't understand, as long as there is a recipe that's reported to me and I am asked to call (laugh) to cook the affairs of all the crew." (Pharmacist 3)

The meaning of the above statement is that there was a complaint from the head of the installation stating that the pharmacists more often reported problems in prescription services through the head of the installation and then the head of the plant that communicated with the doctor. The main reason for this is that the head of the pharmaceutical installation is considered to have better communicating with the doctor.

The pharmacist's confidence can be influenced by his ability in mastering material related to clinical pharmacy. Not all pharmacist graduates have uniform clinical pharmacy skills. In pharmaceutical institution itself, not all institutions have adequate clinical pharmacy curriculum, especially senior pharmacists with old curriculum models. Clinical pharmacy is still considered a strange thing, so it is necessary to increase the pharmacist's knowledge in clinical pharmacy through continuing training or education to build the confidence of the pharmacist to carry out his functions in the hospital. It also needs to be revised to the pharmacist professional education curriculum that focuses on clinical pharmacy which is the focus in pharmaceutical services in hospitals in accordance with standards set by the government.

The role of the Pharmacy and Therapy Committee (KFT) is not yet optimal. The role of KFT in RSUD Rantauprapat can be seen from the following expressions:

"The potential of the KFT is very good to be able to talk about prescribing issues, the use of drugs in hospitals, the potential is very good, very large, back and forth to the commitment to implement it. As for the KFT, but even if there is no meeting a year is the same (laugh). I don't know when I have had a meeting, a year ago I think ((laughing) "(Doctor 2)

"Yes, KFT can do anything, cut the conflict of interest suspicion. That is rife now, what do we do, we have the interests of doctors in the interests of hospitals, want the high cost, want the low cost. "(Doctor 3)

"No, not routinely, in terms of determining therapy, the role of KFT here is usually in the determination of formulary, providing input to the hospital, that we play there discussing with doctors what they need." (Pharmacist 3)

"We are at the KFT meeting, at the KFT meeting the doctor and the pharmacist will be told, fellow doctors can also debate like yesterday who failed to enter the hospital formulary, Farmacon" (Pharmacist 2)

"KFT, the compiler of the hospital's formulary, has been reviewed from there, from its effectiveness then from the price" (Pharmacist 4)

The phrase illustrates that KFT has not performed its role properly as a vehicle that bridges 
communication between doctors and pharmacists. KFT still functions as a hospital formulary maker.

Regulation of the Minister of Health of the Republic of Indonesia number 72 of 2016 states that in the hospital a Pharmacy and Therapy Committee must be formed which is a work unit in providing recommendations to hospital leaders regarding the policy of drug use in hospitals whose members consist of doctors representing all specialties in hospital, pharmacy installation pharmacist, and other health workers if needed.

The Pharmacy and Therapeutics Committee (KFT) at the hospital is also a communication bridge between doctors and pharmacists. This function must be optimized in order to accommodate the gap in relations between doctors and pharmacists in collaboration, so that pharmacists can foster relationships both personally and between professions so that communication between doctors and pharmacists is better. This will facilitate the pharmacist in carrying out his role.

\section{Conclusion}

From the results of this study it can be concluded as follows:

Collaboration of the role of doctors and pharmacists in prescribing rationality. Forms of collaboration between doctors and pharmacists in rational prescribing conducted at Rantauprapat District Hospital include: reviewing prescription contents, solving problems related to drug use and providing drug information.

Constraints on the implementation of the collaboration of the role of doctors and pharmacists. The implementation of the role of the pharmacist in prescribing rationality encountered obstacles, among others: (1) The problem of the quantity and quality of human resources, where in terms of human resources not yet meeting hospital class standards and quality related to limited knowledge of clinical pharmacy; (2) Communication problems with doctors, such as communication barriers between doctors and pharmacists due to doctors who are difficult to communicate with and pharmacists who are not confident in communicating with doctors; (3) The role of the Pharmacy and Therapy Committee (KFT) is not optimal.

Based on the results of this study, researchers provide suggestions:

(1) Increasing human resources both in quantity and quality, among others: (a) Carrying out pharmacists recruitment with clinical pharmacy skills qualifications, (b) Carrying out continuing education and training on clinical pharmacy to pharmacists.

(2) Strengthening policies and evaluating the implementation of pharmaceutical services in hospitals, especially visiting patients with doctors and pharmacists

(3) Building communication relations between doctors and pharmacists through empowering the role of the pharmaceutical and therapeutic committee.

\section{References}

Abdulkadir, W., Suhariadi, F., Wibowo, A., \& Hadi, C., 2017, Three-party (physicianpharmacist-director) collaboration model on teamwork effectiveness improvement in hospital. Open Access Journal of Science and Technology, 5 doi:http://dx.doi.org/10.11131/2017/101156

Agustinova, D. E., 2015, Memahami penelitian kualitatif; teori \& praktik, Yogyakarta, Penerbit 
Calpulis

Ajemigbitse, A., Omole, M., Osi-Ogbu, O., \& Erhun, W., 2013, A qualitative study of causes of prescribing errors among junior medical doctors in a nigeria in-patient setting. Annals of African Medicine, 12(4), 223-31. doi:http://dx.doi.org/10.4103/1596-3519.122691

Anderson, C. M., Croley, K. S., Daniels, C., Ferreri, S. P., Flynn, E., Galdo, J.A., Lorenzen, A., Marcy, T. R.,...Zlott, D. A., 2017, Pharmacist's impact on patient safety, american pharmacist association

Anil Kumar P., Padma L., Veena D.R., Bhaskar R., 2015, Rational prescribing \& prescription writing: role of clinical pharmacologist to improve the patient quality of care, Indian Journal of Pharmacy and Pharmacology, April-June 2015;2(2);134-138

Broom, A., Broom, J., Kirby, E., Plage, S., Adams J., 2015, What role do pharmacist playing mediating antibiotic used in hospitals?; A Qualitative Study, BMJ Open 2015;5:e008326. doi:10.1136/bmjopen-2015-008326

Bungin, B., 2017, Penelitian kualitatif ;komunikasi ekonomi, kebijakan publik dan ilmu sosial lainnya, Edisi Kedua, Jakarta, Penerbit Kencana

Cufar et al.: Attitudes of physicians, nurses and pharmacists concerning the development of clinical pharmacy activities in a university hospital, Acta Pharm.64 (2014) 447-461De Vries, T. P. G. M., Henning, R. H., Hogerzel, H. V., Fresle, D. A., 2014, Guide to good prescribing, world health organization, Action programme on essential drugs, Geneva

Dean, B., Schachter, M., Vincent, C., \& Barber, N., 2016, Causes of prescribing errors in hospital inpatients: A prospective study. The Lancet, 359(9315), 1373-8. doi:http://dx.doi.org/10.1016/S0140-6736(02)08350-2

Emzir, 2014, Metodologi penelitian kualitatif: analisis data, Edisi 1, Cetakan keempat, Jakarta, Rajawali Press

Hansen,C.R., Walsh, E.K., Bradley, C.P., Sahm, L.J., 2017, Teaching prescribing: just what the doctor ordered? a thematic analysis of the views of newly qualified doctors, MDPI Pharmacy Journal, doi:10.3390/pharmacy5020032

Hashemian F, Emadi, F., Roohi, E., 2016, Collaboration between pharmacists and general practitioners in the health care system in the Islamic Republic of Iran, Eastern Mediterranean Health JournalLa Revue de Santé de la Méditerranée orientale Vol. 22 No. 6. Hal 375-382

Hidayat, Z. S., Purwonugroho, T.A., dan Vera RU, V.V., 2014, Analisis Persepsi dan Harapan Dokter terhadap Peran Apoteker di RSUD Prof. Dr. Margono Soekarjo Purwokerto, Supplemen 1.4ajalah Kedokteran Andalas, Vol, 37, No Supl 1, Halaman 79-87.

Ikawati, Z., 2016, Farmasi Klinis Terbukti Efektif Tingkatkan Hasil Terapi pada Pasien, https://ugm.ac.id/id/news, diakses 30 September 2019.

Institute of medicine, 2006, Preventing medication errors, report Brief

Komite Keselamatan Pasien Rumah Sakit, (2011), Laporan insiden keselamatan pasien, Jakarta, KKP RS.

Kementerian Kesehatan Republik Indonesia, 2011, Modul Penggunaan Obat Rasional, Direktur Bina Pelayanan Kefarmasian, Jakarta

Kementerian Kesehatan Republik Indonesia, 2016, Peraturan Menteri Kesehatan Republik Indonesia Nomor 72 Tahun 2016 Tentang Standar Pelayanan Kefarmasian di Rumah Sakit

Kementerian Kesehatan Republik Indonesia, 2018, Peraturan Menteri Kesehatan Republik Indonesia Nomor 4 Tahun 2018 tentang Kewajiban Rumah Sakit dan Kewajiban Pasien, Jakarta

Lal, L. S., Rosenau, P. V., 2015, Evaluation of rational use of medications in the united states, Journal of primary care \& community health 1(1) 62-68 sagepub.com/journals Permissions.nav DOI: $10.1177 / 2150131909356446$ http://jpc.sagepub.com

Mao, W., Vu, H., Xie, Z., Chen, W., \& Tang, S., 2015, Systematic review on irrational use of medicines in china and vietnam. PLoS One, 10(3) doi:http://dx.doi.org/10.1371/journal.pone.0117710 
Mahmood, A., Elnour, A. A., Ali, A. A. A., Hassan, N., Sheehab, A., Srikanth, A., 2015, Evaluation Of Rational Use Of Medicines (RUM) In four government hospitals in UAE, Saudi Pharmacentical Journal, King Saud University, http://dx.doi.org/10.1016/i.jsps.2015.03.003

Ofori-Asenso, R., \& Agyeman, A. A. (2016). Irrational use of medicines-A summary of key concepts. Pharmacy, 4(4), 35-n/a. doi:http://dx.doi.org/10.3390/pharmacy4040035

Pengurus Pusat Ikatan Apoteker Indonesia, 2016, Standar Kompetensi Apoteker Indonesia

Rony, Z. T., 2017, Siap fokus, siap menulis, skripsi, Tesis, Disertasi; Jurus mudah Gunakan Metode Kualitatif Tipe Studi Kasus, Pusat Studi Sumber daya Manusia, Jakarta

Simatupang, A., 2014, Pedoman WHO tentang Penulisan Resep yang Baik sebagai Bagian Penggunaan Obat yang Rasional, (Tesis Universitas Kristen Indonesia) Bagian Farmakologi Fakultas Kedokteran Universitas Kristen Indonesia. Diakses dari https://www.academia.edu/5065317

Sztankovszky, L-Z, Magdalena, I., 2015, Ethical Practices In Drug Prescribing. A Comparative Study Between Doctors' And Pharmacists' Opinion About Drug Prescribing In Romania, AGATHOS, Volume 6, Issue 2

Thomas, L. J., \& Coleman, J. J. (2007). The medic's guide to prescribing: Rational prescribing. Student BMJ, 15 doi:http://dx.doi.org/10.1136/sbmj.0704144

World Health Organization, 2017, Guide to Good Prescribing; A Practical Manual, World Health Organization Action Programme on Essential Drugs, WHO/DAP/94.11-Distr: GeneralOriginal: English, Geneva

Zaman, N., Joenoes, 1990, ARS PRESCEBENDI-Penulisan Resep yang Rasional, Jilid I \& II, Surabaya, Airlangga University Press 